\title{
Araceae do Parque Estadual do Rio Doce, MG, Brasil
}

\author{
Lívia Godinho Temponi ${ }^{1,4}$, Flávia Cristina Pinto Garcia² ${ }^{2}$ Cássia Mônica Sakuragui ${ }^{3}$ e \\ Rita Maria de Carvalho-Okano ${ }^{2}$
}

Recebido em 7/01/2005. Aceito em 11/07/2005

\begin{abstract}
RESUMO - (Araceae do Parque Estadual do Rio Doce, MG, Brasil). O presente trabalho consta do estudo taxonômico das espécies de Araceae que ocorrem no Parque Estadual do Rio Doce, com chaves dicotômicas, descrições e ilustrações botânicas. Foram realizadas excursões mensais de maio/1999 a abril/2000 para coleta do material botânico, ao longo de 11 trilhas preestabelecidas nas regiões central e sul do parque. São reconhecidas 13 espécies, pertencentes a oito gêneros, sendo Philodendron o mais representativo com três espécies. Quatro das espécies encontradas no Parque são novos registros para Minas Gerais: Asterostigma concinnum Schott, Heteropsis flexuosa (Kunth) G.S. Bunting, Philodendron speciosum Schott e Philodendron vargealtense Sakuragui.
\end{abstract}

Plavras-chave: Araceae, Taxonomia, Floresta Atlântica, Parque Estadual do Rio Doce

\begin{abstract}
Araceae of Rio Doce State Park, Minas Gerais State, Brazil). A taxonomic study of the Araceae species found in Rio Doce State Park is presented, with dichotomous keys, botanical descriptions and illustrations. Monthly trips took place from May 1999 to April 2000 to collect botanical material. Collections were made along 11 trails in the central and southern regions of the park. Thirteen species belonging to eight genera were recorded; Philodendron was the most representative with three species. Four of the species found at Park are new records for Minas Gerais: Asterostigma concinnum Schott, Heteropsis flexuosa (Kunth) G.S. Bunting, Philodendron speciosum Schott and Philodendron vargealtense Sakuragui.
\end{abstract}

Key words: Araceae, taxonomy, Atlantic rain forest, Rio Doce State Park

\section{Introdução}

O Parque Estadual do Rio Doce, com cerca de 36.000 ha, está localizado entre os paralelos 1929'24'$19^{\circ} 48^{\prime} 18^{\prime \prime} \mathrm{S}$ e os meridianos $42^{\circ} 28^{\prime} 18^{\prime \prime}-42^{\circ} 38^{\prime} 30^{\prime \prime} \mathrm{W}$. Apresenta um sistema de 38 a 44 lagoas (cerca de $6 \%$ da área) que exercem papel importante na criação de micro-hábitats. A altitude varia de 230 a 515 m acima do nível do mar e, de acordo com a classificação de Köppen, o Parque está situado em uma região de clima do tipo Aw (tropical úmido de savana, megatérmico), com períodos de chuvas e estiagem bem definidos. A vegetação é considerada como Floresta Estacional Semidecidual Submontana (Veloso et al. 1991). Aubrèville (1959) a incluiu nos domínios da Floresta Atlântica

A maior diversidade da família Araceae é verificada nas florestas tropicais úmidas (Mayo et al. 1997), sendo um dos centros de diversidade a Floresta Atlântica (Mayo 1990). Entretanto, a família tem sido pouco estudada taxonomicamente e raramente incluída em levantamentos florísticos e/ou fitossociológicos. Recentemente, várias espécies novas têm sido descritas para o Brasil e algumas destas endêmicas para Minas Gerais (Sakuragui \& Mayo 1997; Gonçalves 2001) confirmando a necessidade de coletas e estudos para a família no Estado.

O estudo taxonômico da família no Parque Estadual do Rio Doce, teve como objetivo fornecer informações sobre a morfologia das espécies de Araceae, bem como contribuir com o conhecimento da flora de Minas Gerais $\mathrm{e}$, conseqüentemente, do Brasil.

\section{Material e métodos}

As coletas de material botânico foram realizadas mensalmente de maio/1999 a abril/2000 e também de outubro a dezembro/2000, ao longo das trilhas e estradas preestabelecidas (listagem dos pontos diponíveis com as autoras). Representantes de Araceae

\footnotetext{
Universidade Federal de Viçosa, Instituto de Biologia Vegetal, Programa de Pós-Graduação em Botânica, CEP 36570-000, Viçosa, MG, Brasil

Universidade Federal de Viçosa, Instituto de Biologia Vegetal, CEP 36.570-000, Viçosa, MG, Brasil

Universidade Estadual de Maringá, Av. Colombo 3690, CEP 80001-970, Maringá, PR, Brasil

4 Autor para correspondência: liviatemponi@bol.com.br
} 
férteis foram coletados e herborizados de acordo com as técnicas específicas para espécimes da família (Croat 1985) e incluídos no Herbário VIC, do Departamento de Biologia Vegetal, da Universidade Federal de Viçosa.

A identificação do material botânico foi realizada mediante literatura especializada (Schott 1859; Engler 1878; Mayo 1991; Mayo et al. 1997) e consultas aos herbários BHCB, R, RJ, SP e SPF. Os autores das espécies foram citados seguindo Brummitt \& Powell (1992).

Os termos morfológicos das partes vegetativas e reprodutivas foram baseados nos trabalhos de Radford et al. (1979), Croat \& Bunting (1979), Mayo (1991), Mayo et al. (1997), Temponi et al. (2005). Adotou-se a definição de Madison (1977) para descrição do pecíolo. A medida de diâmetro de pecíolo foi tomada no ápice e quando este era geniculado a medida foi tomada anteriormente ao genículo. As demais medidas de diâmetro, assim como as de largura foram realizadas na região da estrutura de maior diâmetro ou largura, respectivamente.

\section{Resultados e discussão}

Araceae Juss., Gen. Pl. 23 (1789, “Aroideae") nom. cons.
Ervas perenes ou sazonais; caules aéreos eretos, trepadores, reptantes ou subterrâneos, rizomatosos ou tuberosos, entrenós com raízes adventícias. Folhas alternas, pecioladas, invaginantes na base; lâminas simples inteiras, tripartidas, pinatífidas ou compostas palmadas, pinadas; venação reticulada, peniparalelinérvea ou colocasióide. Inflorescências terminais pseudolaterais, 1-várias, última folha do artículo formando uma espata; espádice com flores bi ou unissexuais, neste caso com flores femininas na base e masculinas no ápice, geralmente com flores masculinas estéreis intercaladas. Flores aperiantadas ou com perianto tepalóide bastante reduzido, hipóginas, actinomorfas, protogínicas; estames livres ou conatos, anteras geralmente extrorsas; gineceu gamocarpelar, 1-47 locular; óvulos 1-numerosos. Infrutescência constituída por várias bagas parcialmente isoladas ou sincárpicas; semente com ou sem endosperma, testa fina a espessada.

Resultaram desse estudo 13 espécies distribuídas em oito gêneros: Anthurium (2 espécies), Asterostigma (1), Heteropsis (2), Monstera (2), Philodendron (3), Rhodospatha (1), Syngonium (1), Xanthosoma (1). Das espécies encontradas no Parque Estadual do Rio Doce, quatro são novos registros para Minas Gerais.

Chave para identificação dos gêneros de Araceae do Parque Estadual do Rio Doce (PERD)

1. Planta geófita ou helófita

2. Planta geófita, dormente na estação seca; 1 folha pinatífida; gineceu com estilete definido; estigma astericiforme 2. Asterostigma

2. Planta helófita, perene; multifoliada, folhas sagitadas ou oblongas a elípticas; gineceu sem estilete definido; estigma discóide

3. Folhas sagitadas, venação colocasióide; espata fortemente constricta (diferenciada em lâmina e tubo), apenas a lâmina da espata descídua pós-antese; flores unissexuais

8. Xanthosoma

3. Folhas oblongas a elípticas, venação peniparalelinérvea; espata não constricta (não diferenciada em lâmina e tubo), totalmente descídua pós-antese; flores bissexuais 6. Rhodospatha

1. Planta hemi-epífita ou epífita

4. Planta latescente; lâmina sagitada em plantas jovens, tripartida-hastada quando adulta; bagas conatas em um sincarpo indeiscente

7. Syngonium

4. Planta sem látex; lâmina elíptica, ovada ou palmada, bagas livres

5. Venação peniparalelinérvea; espádice heterogêneo; flores femininas na base 5. Philodendron

5. Venação reticulada; espádice homogêneo; flores bissexuais

6. Catafilos persistentes, desmanchando em fibras; espata persistente; perigônio evidente

1. Anthurium

6. Catafilos caducos; espata decídua após a antese; perigônio ausente

7. Caule com crescimento monopodial; pecíolo $<2 \mathrm{~cm}$ compr.; espádice estipitado

7. Caule com crescimento simpodial; pecíolo $>5$ cm compr.; espádice séssil 
1. Anthurium Schott, Wiener Z. Kunst 3: 828. 1829.

Erva perene, usualmente epífita, hemi-epífita, menos freqüentemente terrestre, sem látex; caule com crescimento simpodial, ramo flageliforme ausente; profilo caduco, catafilo geralmente persistente ou desmanchando em fibras castanhas. Folha simples ou composta; pecíolo conspicuamente geniculado no ápice; lâmina inteira ou palmatipartida, às vezes com pontuações glandulares negras; nervuras laterais primárias pinadas, formando nervura coletora submarginal, laterais secundárias e terciárias reticuladas. Inflorescência terminal, 1 por axila foliar, densiflora; espata persistente, não constricta, ereta aberta ou reflexa, linear ou linear-lanceolada; espádice séssil a longo estipitado, não adnato à espata, homogêneo, sem regiões distintas. Flores bissexuais, monoclamídeas; dois verticilos decussados, tépalas 4, cuculadas, ápice truncado, usualmente cobrindo o pistilo; estames 4, livres; ovário 2-locular, 1-2-(3-) óvulos por lóculo, placentação axial ou axial-apical, região estilar indiferenciada. Fruto isolado, geralmente subgloboso; semente oblonga a elipsóide ou subglobosa.

Chave para a identificação das espécies de Anthurium

1. Hemi-epífita; folha palmada, sem glândulas punctiformes negras na face abaxial; espádice $>4 \mathrm{~cm}$ compr., $5 \mathrm{~mm}$ diâm.; bagas vináceas; 2 sementes

1. Epífita; folha simples, com glândulas punctiformes negras na face abaxial; espádice até $2,5 \mathrm{~cm}$ compr., $4 \mathrm{~mm}$ diâm.; bagas branco-esverdeadas; 4 sementes 1.2. A. scandens

\subsection{Anthurium pentaphyllum (Aubl.) G. Don, Sweet,} Hort. Brit. ed. 3. 633. 1839.

Fig. 1-5

Hemi-epífita, catafilo 28-87×12-39 mm, desmanchando em fibras; cicatriz do profilo 20-25 mm larg., anelar; cicatriz foliar 5-11×4-9 mm, ovóide, castanha. Folha composta; pecíolo 43-74,8×0,2-0,6 cm, levemente sulcado; peciólulo 1,5-5 cm compr.; lâmina jovem trifoliolada, adulta 7-11-foliolada; folíolo 12,8-32x 3,4-11 cm, elíptico a obovado, ápice acuminado a longoacuminado, base cuneada-oblíqua, margem inteira a levemente ondulada, cartácea, verde-nítido na face adaxial, sem pontuações negras na face abaxial, nervuras laterais primárias 7-12 pares. Pedúnculo 29-95×2-4,5 mm, ereto, verde; espata 52-71×11-34 mm, reflexa ou não, verde em ambas as faces, persistente; espádice séssil, 42-119×6-12 mm, uniformemente afilado. Tépalas retangulares, 3-3,5×2,5-3 mm; estames 4, filete espessado, ca. $2,5-3 \times 1,5 \mathrm{~mm}$; gineceu 2,8-3,5×1,5-2,5 mm, alvo, 1 óvulo por lóculo, placentação axial-apical. Infrutescência $85-150 \times$ 12-24 mm; pedúnculo ereto, 112-190×3-5 mm; espata verde com estrias vináceas em ambas as faces. Fruto maduro 7-9×5,5-7 mm, subgloboso, vináceo, maturação acrópeta; semente 4,5-5×3,5-4 mm, 2 por baga, oblonga-elipsóide, levemente falcada, lisa.

Anthurium pentaphyllum é espécie amplamente distribuída nas florestas brasileiras e foi encontrada no Parque do Rio Doce na maioria das trilhas percorridas, sempre em áreas fechadas do sub-bosque. Floresceu em dezembro, janeiro e março e frutificou em vários meses do ano.

Material selecionado: BRASIL. Minas Gerais: Marliéria, PERD: Trilha do Aníbal, 17/I/2000, bo. fl., Temponi et al. 86 (VIC); Trilha da Campolina, 14/XII/2000 fl. fr., Temponi et al. 217 (VIC); Trilha da Lagoa do Meio, 21/XII/1999, bo fl., L.G. Temponi et al. 78 (VIC); Trilha da Mumbaça, 11/VII/1999, fr., Temponi et al. 47 (VIC); Trilha do Vinhático, 23/III/2000, bo. fl. fr., Temponi et al. 99 (VIC); Dionísio, Fazenda do José Gomes, 8/VI/2000, fl. fr., Temponi et al. 119 (VIC).

1.2. Anthurium scandens (Aubl.) Engl., Martius, Fl. Bras. 3, pt.2: 78. 1878.

Fig. 6-11

Epífita; catafilo desmanchando em fibras. Folha simples; pecíolo 22-47×1-1,5 mm, levemente sulcado, lâmina elíptica, 10,3-14,4×3-3,5 cm, ápice agudo, base cuneada, margem inteira, cartácea, levemente discolor, verde-nítido na face adaxial, com pontuações negras na face abaxial; nervuras laterais primárias 11-16 pares. Pedúnculo 14-28×1-2 mm, ereto, verde; espata 15-18×5,5-6,5 mm, reflexa, verde, persistente; espádice curto estipitado, 21-24×3-4 mm, uniformemente afilado; estípite ca. $1 \mathrm{~mm}$ compr. Tépalas obtriangulares, 1-1,5×1-1,5 mm; estames 4, filete delgado, ca. 1-1,5×0,7-0,8 mm; gineceu 1-1,2× 1,2-1,5 mm, esverdeado, 2 óvulos por lóculo, placentação axialapical. Infrutescência 29-51× 5-16 mm; pedúnculo 14-28 $\times 1-2 \mathrm{~mm}$, ereto a pêndulo; espata verde com estrias levemente vináceas. Fruto maduro 6,5-7x 7-7,5 mm, globoso, branco, maturação simultânea; semente 2,5-3×1,5-2 mm, 4 por baga, elipsóide, 


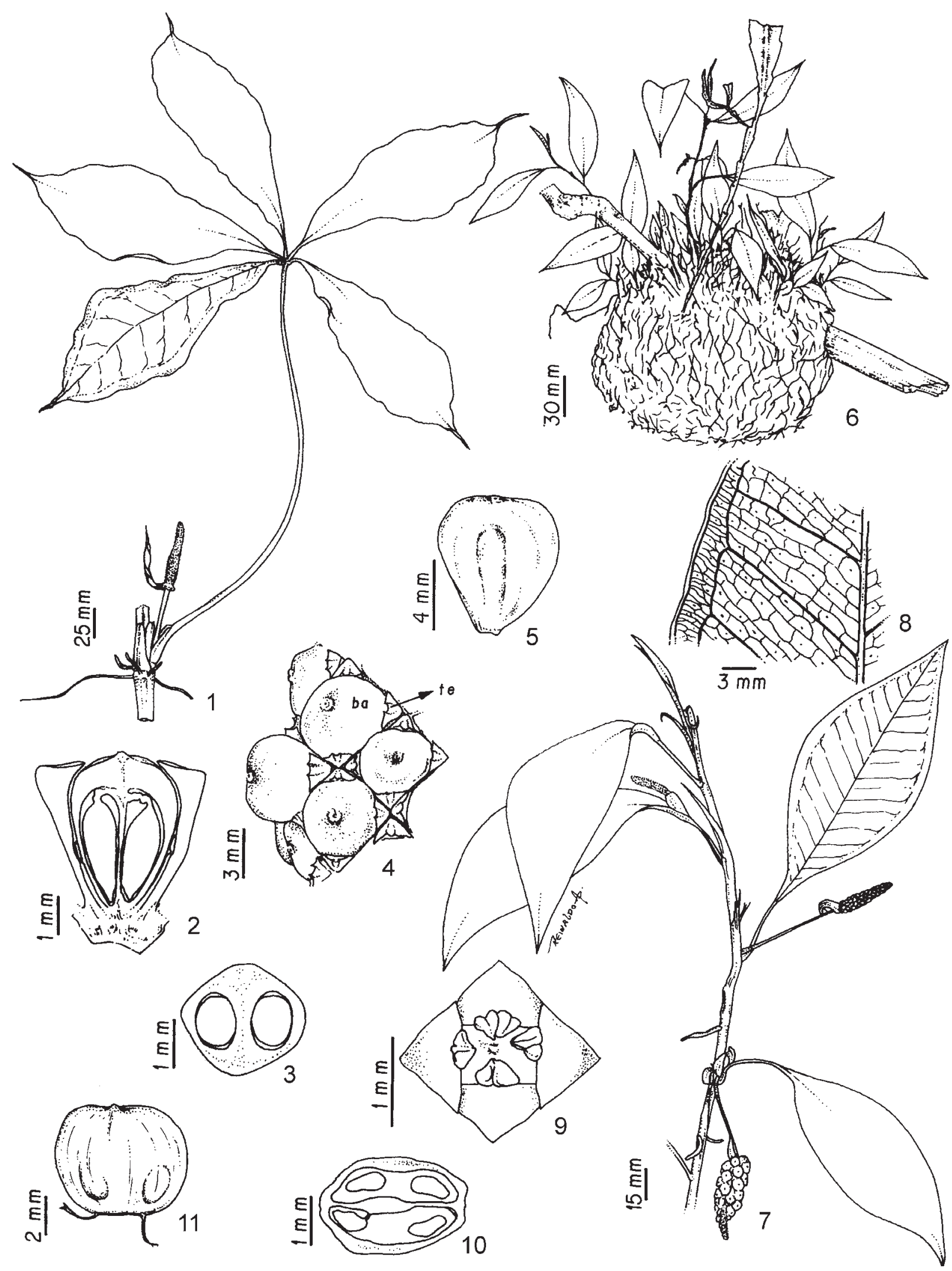

Figuras 1-11. Espécies de Anthurium do Parque Estadual do Rio Doce. 1-5. A. pentaphyllum (Aubl.) G. Don. 1. Aspecto geral do ramo. 2. Corte longitudinal da flor. 3. Corte transversal do ovário. 4. frutos, ba = bagas e te = tépalas. 5. Vista longitudinal da baga (Temponi et al. 119 e 217). 6-10. A. scandens (Aubl.) Engl. 6. Raízes associadas, formando ninho de formigas. 7. Aspecto geral do ramo. 8. Venação reticulada. 9. Vista frontal da flor. 10. Corte transversal do ovário. 11. Vista longitudinal da baga (Temponi et al. 193). 
levemente falcada, estriada.

Anthurium scandens é espécie neotropical, amplamente distribuída na Mata Atlântica brasileira, mas no Parque Estadual do Rio Doce somente foi encontrada no dossel e em duas trilhas. Distingue-se das demais espécies ocorrentes no Parque pelo hábito epifítico, e suas raízes ocorrerem associadas às de Bromeliaceae e Cactaceae, formando ninhos de formigas. É espécie de floração contínua e a frutificação ocorreu de agosto a dezembro.

Material selecionado: BRASIL. Minas Gerais: Marliéria, PERD: Trilha do Aníbal, 10/IX/2000, bo. fl. fr., Temponi et al. 193 (VIC); Trilha da Lagoa do Meio, 3/VI/1998, fr., Temponi 11 (BHCB).

2. Asterostigma Fisch. \& A.C. Mey., Bull. Cl. PhysMath. Acad. Imp. Sci. Saint-Petersbourg ser. 2,3:148. 1845.

Erva sazonal, geófita, com látex; caule tuberoso, globoso ou depresso; profilo geralmente marcescente. Folha usualmente simples, solitária; pecíolo não geniculado no ápice, freqüentemente maculado; lâmina geralmente pinatissecta; nervuras laterais primárias pinadas, laterais secundárias e ordens superiores reticuladas. Inflorescência 1-3 por axila foliar, laxiflora pelo menos na base; espata persistente, constricta ou não, convoluta na base, ereta, aberta; espádice séssil a longo estipitado, livre ou parcialmente adnato à espata, heterogêneo, região basal com flores femininas, seguida da região com flores masculinas, até o ápice. Flor unissexual, aclamídea; flor masculina, 3-4 estames conatos em um sinândrio; flor feminina, gineceu 3-5locular, circundado por sinandródios, 1 óvulo por lóculo, placentação axial-basal, região estilar distinta, mais delgada que o ovário, estigma astericiforme. Fruto isolado, subgloboso, sulcado; semente oblonga a elipsóide.

\subsection{Asterostigma luschnathianum Schott, Syn.} Aroid. 126. 1856.

Fig. 12-16

Geófita, caule 8,5-26×7-3 mm, branco leitoso internamente; catafilos 11,5-21,5×1,7-2,6 cm. Pecíolo 29-43×0,2-0,3 cm, ereto, cilíndrico, verde com manchas vináceas a negras; lâmina jovem sagitada, adulta pinatífida, 11-24,5×14,5-29 cm, membranácea, verdenítido em ambas as faces, às vezes, com manchas brancas na face adaxial; divisão anterior: 5-(6) lobos laterais, lobos laterais elípiticos a obovados, ápice agudo a acuminado, base cuneada ou cuneada no lado acroscópico e decurrente no basioscópico, margem inteira a levemente ondulada, nervuras laterais primárias 6-9 pares; divisões posteriores: porção acróspica e basioscópica com 1 lobo, quando 2 não inteiramente livres, base, ápice, margem e número de nervuras, similares aos da divisão anterior. Inflorescência 1-(2) por axila foliar; pedúnculo até $36,5 \times 1,5-7 \mathrm{~mm}$, ereto, cilíndrico, verde com manchas vináceas; espata $67-91 \times 18-2 \mathrm{~mm}$, ereta, esverdeada internamente, com leves estrias vináceas externamente, persistente; espádice estipitado, 45-67 mm compr.; zona estaminada $32-38 \times 3-4,5 \mathrm{~mm}$, vinácea; zona pistilada 21-26×4,5-6 mm com 9,5-12 mm compr. adnato à espata, verde-rosado; estípite 4,5-9,5 mm. Flor masculina $15-20 \times 35-50 \mathrm{~mm}, 3-4$ estames, formando sinândrio vinho; flor feminina 20-25×30-45 mm, 3 estaminódios com projeções alongadas, livres, rosaamarelados, ovário globoso, (2)-3-(4)-locular, estigma astericiforme, ca. 1,5 mm, (2)-3-(4) lobos agudos, rosados. Infrutescência 37-45×8-15 mm, verdeamarelada. Fruto imaturo, subgloboso, 2-5 sulcado; semente 2-4 por baga.

Esta espécie ocorre no sudeste do Brasil (Gonçalves 1999). No Parque Estadual do Rio Doce, A. luschnathianum foi encontrada em apenas três trilhas. Distingue das demais espécies do Parque por ser geófita, apresentar folha pinatífida e estigma astericiforme. Floresceu de outubro a dezembro e frutificou de dezembro a fevereiro.

Material selecionado: BRASIL. Minas Gerais: Marliéria, PERD: Trilha da Campolina, 21/XII/1999, fr., Temponi et al. 80 (VIC); Trilha da Lagoa do Meio, 22/XI/1999, bo. fl., Temponi et al. 74 (VIC); Trilha do Vinhático, 16/XI/2000, bo. fl., Temponi et al. 182 (VIC).

\section{Heteropsis Kunth, Emun. Pl. 3:59. 1841.}

Erva perene, epífita ou hemi-epífita, sem látex; caule com crescimento monopodial, ramo flageliforme presente; catafilo decíduo. Folha simples; pecíolo usualmente muito curto, inteiramente geniculado; lâmina inteira, elíptica a oblonga; nervuras laterais primárias pinadas, laterais secundárias mais ou menos paralelas às primárias, formando nervura coletora submarginal, laterais terciárias e ordens superiores reticuladas. Inflorescência solitária em ramos floríferos, densiflora; espata caduca, não constricta, ereta aberta na antese, ovada-elíptica a ovada-oblonga; espádice estipitado, não adnato à espata, homogêneo, sem regiões distintas. Flores bissexuais, aclamídeas; estames 4 ou menos, livres; ovário incompletamente 2-locular, 2 óvulos por lóculo, placentação axial-basal, região estilar distinta, mais larga que o ovário. Fruto isolado, ovóide a mais ou menos prismático; semente obovóide a elipsóide. 
Chave para identificação das espécies de Heteropsis

1. Pecíolo acima de $1 \mathrm{~cm}$ compr., lâmina foliar coriácea a subcoriácea, acima de $5 \mathrm{~cm}$ larg.; inflorescência com 7-8 fileiras de flores espiraladas 3.1. H. flexuosa

1. Pecíolo até $7 \mathrm{~mm}$ compr., lâmina foliar membranácea a cartácea, até $4,5 \mathrm{~cm}$ larg.; inflorescência com 9-11 fileiras de flores espiraladas 3.2. H. salicifolia

3.1. Heteropsis flexuosa (Kunth) G.S. Bunting, Rev. Fac. Agron. 10(1-4): 201. 1979.

Fig. 17-19

Hemi-epífita; ramo flageliforme presente. Folha simples; pecíolo 0,6-1,3 cm compr., côncavo, inteiramente geniculado; lâmina obovada a oblonga, $(11,5) 17-21 \times(2,8) 5-7 \mathrm{~cm}$, ápice agudo a acuminado, base cuneada, margem inteira, cartácea a subcoriácea, discolor, verde oliva na face adaxial, verde-amarelada; nervuras laterais primárias mais de 15 pares, inconspícuas na face adaxial, levemente impressas na face abaxial. Pedúnculo 3-4×3 mm, ereto, verde; espata 19-29×12 mm, amarelada, decídua após antese; espádice curto estipitado, $175-220 \times 5,5-8 \mathrm{~mm}, 7-8$ fileiras de flores, 3-5 flores por espiral; estípite 3-4 mm compr. Estames 4, filete achatado; gineceu, prismático, amarelo, 2 óvulos por lóculo, estigma ca. $0,5 \mathrm{~mm}$ compr., alongado, fendido no centro, marrom. Infrutescência $28-77 \times 10-29 \mathrm{~mm}$, verde; pedúnculo ereto. Fruto imaturo subprismático; semente 3-4 por baga, elipsóide.

Através da análise dos espéciemes encontrados em diversos herbários, verificou-se que Heteropsis flexuosa ocorre na região norte do Brasil, sendo este o primeiro registro para Minas Gerais e também para a região Sudeste. Esta espécie foi encontrada em apenas duas trilhas, próximas às margens das lagoas. A espécie floresceu e frutificou de outubro a janeiro.

Material selecionado: BRASIL. Minas Gerais: Marliéria, PERD: Margem da Lagoa Dom Helvécio, 13/XII/2000, est., Temponi et al. 205 (VIC); Trilha do Aníbal, 17/I/2000, bo. fr., Temponi et al. 85 (VIC); Trilha da Campolina, 15/VIII/2000, est., Temponi et al. 138 (VIC); Trilha da Lagoa do Meio, 31/X/1999, fr., Temponi et al. 61 (VIC); Trilha da Lagoa Preta, 15/VIII/2000, est., Temponi et al. 137 (VIC).

3.2. Heteropsis salicifolia Kunth, Enum. 3: 60. 1841. Fig. 20-24
Hemi-epífita; ramo flageliforme não visto. Folha simples; pecíolo 3-7×2-3 mm, côncavo, inteiramente geniculado; lâmina obovada a oblonga, 6-17×1,8-4,5 cm, ápice agudo a acuminado, base cuneada, margem inteira, membranácea a cartácea, levemente discolor, verde-nítido na face adaxial, verde-amarelado na superfície abaxial; nervuras laterais primárias, mais de 15 pares, inconspícuas na face adaxial, levemente impressas na abaxial. Pedúnculo 5-8×2,5-3 mm, ereto, verde; espata $32,5-38 \times 25,5-29 \mathrm{~mm}$, verde amarelada, decídua após antese; espádice curto estipitado 25-28× 7-9 mm (em pré-antese), 9-11 fileiras de flores, 4-5 flores por espiral; estípite 2-8 mm compr. Estames 4, filete achatado; gineceu prismático, amareloesverdeado, 2 óvulos por lóculo, estigma ca. $0,5 \mathrm{~mm}$ compr., alongado, fendido no centro, marrom. Infrutescência 23-50×8-17 mm, verde; pedúnculo ereto. Fruto imaturo subprismático; semente 3-4 por baga, elipsóide.

Heteropsis salicifolia é espécie frequiente nas matas do sul e sudeste brasileiro e também no Parque Estadual do Rio Doce, foi encontrada em muitas das trilhas percorridas. A espécie foi encontrada em préantese e antese apenas em março e em frutificação durante vários meses, o que revela a dificuldade de se visualizar as inflorescências desta espécie.

Material selecionado: BRASIL. Minas Gerais: Marliéria, PERD: Margem da Lagoa Dom Helvécio, 13/XII/2000, fr., Temponi et al. 206 (VIC); Trilha do Anibal, 6/VI/2000, fr., Temponi et al. 113 (VIC); Trilha da Campolina 28/VIII/1993, fl., Borba 28 (BHCB); Trilha da Mumbaça, 16/VIII/2000, fr., Temponi et al. 148 (VIC); Trilha da Lagoa do Meio, 24/III/2000, bo. fl., L.G. Temponi et al. 102 (VIC); Trilha da Lagoa Preta, 16/X/2000, fr., Temponi et al. 153 (VIC).

\section{Monstera Adans. Fam. Pl. 2: 470. 1763.}

Erva perene, epífita, hemi-epífita, caule com crescimento simpodial, profilo decíduo. Folha simples; pecíolo geniculado no ápice, canaliculado; lâmina inteira, elíptica a ovado-elíptica, geralmente fenestrada; nervuras laterais primárias pinadas, laterais secundárias mais ou menos paralelas às primárias, laterais terciárias reticuladas. Inflorescência 1-várias por axila foliar, densiflora; espata caduca, não constricta, ereta aberta, ovada ou oblongo-ovada; espádice séssil, não adnato à espata, homogêneo, sem regiões distintas, mas poucas flores basais usualmente estéreis. Flores bissexuais, aclamídeas; estames 4, livres, filetes achatados; ovário 2-locular, 2 óvulos por lóculo, placentação axial-basal, região estilar distinta; flores estéreis, 4 estaminódios, pistilódios 2-locular, sem óvulos. Fruto isolado, região 


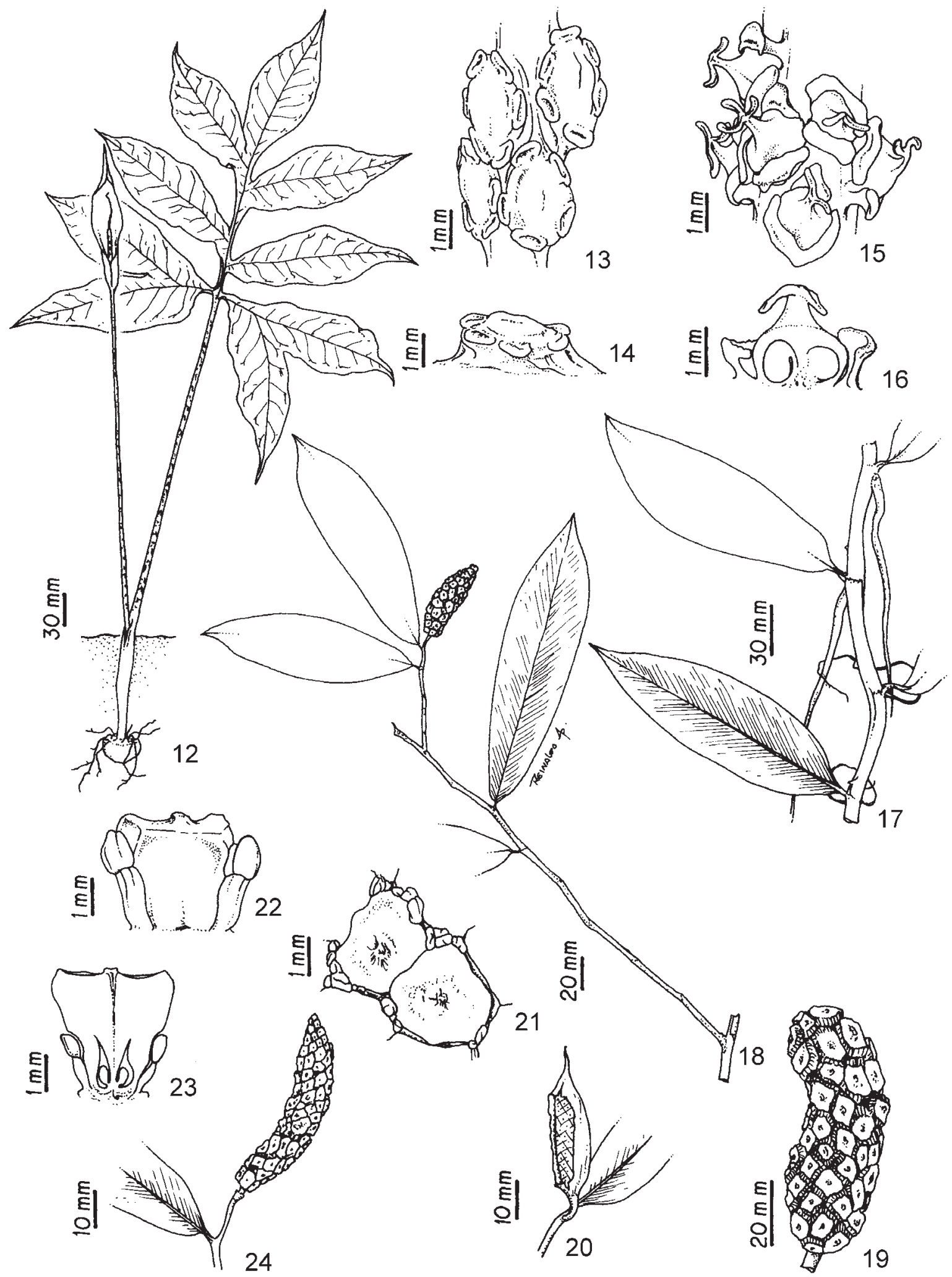

Figuras 12-24. Espécies de Asterostigma e Heteropsis do PERD: 12-16. A. luschnathianum Schott. 12. Hábito. 13. Vista frontal das flores masculinas (sinândrios). 14. Vista longitudinal do sinândrio. 15. Vista frontal das flores femininas. 16. Corte longitudinal da flor feminina, estaminódios circundando o ovário (Temponi et al. 221). 17-19. H. flexuosa (Kunth) G.S. Bunting. 17. Aspecto geral do ramo. 18. Fruto imaturo no ramo lateral. 19. Detalhe dos frutos (Temponi et al. 138 e 194). 20-24. H. salicifolia Kunth. 20. Inflorescência em pré-antese. 21. Vista frontal das flores. 22. Vista longitudinal da flor. 23. Corte longitudinal da flor. 24. Detalhe do fruto imaturo (Temponi et al. 102). 
estilar desprendendo-se na maturidade, polposo internamente; semente ovóide a elipsóide.

Chave para identificação das espécies de Monstera

1. Bainha permanente; espádice creme, $>8,5 \mathrm{~cm}$ compr.; flores basais estéreis; baga subglobosa, branca .......... 4.1. M. adansonii

1. Bainha decídua; espádice amareloalaranjado, até $4 \mathrm{~cm}$ compr.; flores funcionais em todo o espádice; baga prismática, alaranjada ........ 4.2. M. praetermissa

4.1. Monstera adansonii Schott, Wien. Zetschr. 4: 1028.1830 .

Fig. 25-28

Hemi-epífita. Folha simples; pecíolo 24-59x 0,45-1,7 cm, canaliculado; lâmina elíptica-ovada, fenestrada ou não, 23,5-66,5×14-46 cm, ápice agudo, base cuneada a arredondada, margem inteira, cartáceae, levemente discolor, verde nítido na face adaxial, amarelada na abaxial, nervuras laterais primárias 11-21 pares. Inflorescência uma por axila foliar; pedúnculo verde, $105-250 \times 4-9 \mathrm{~mm}$, ereto; espata 11-21×7-14 cm, creme a amarelo pálida com margem esverdeada, decídua após antese; espádice séssil, 8,5-17×1-2 cm, creme. Flor aclamídea; estames 4; antera rimosa; gineceu prismático, ovário creme, 2 lóculos completos, 2 óvulos por lóculo, região estilar mais larga que o ovário, alva, estigma ca. 0,2-0,3 mm compr., alongado, fendido no centro, levemente alaranjado na antese. Infrutescência 15-20,5×2-2,9 cm, alva; pedúnculo ereto. Fruto 7,5-14,5×4,5-7,5 mm, subgloboso; semente 7,5-9,5×6-8,5 mm, ovóide, lisa, 1 por baga, quando 2 , menores e disformes.

Monstera adansonii é muito comum no Brasil e como verificado no Parque Estadual do Rio Doce é uma espécie encontrada tanto no interior da mata quanto em áreas abertas. Diferentemente da maioria das espécies, foi observada em estádio reprodutivo ao longo de todo o período de coleta, sugerindo uma floração e frutificação contínua.

Material selecionado: BRASIL. Minas Gerais: Marliéria, PERD: Estrada Cava Grande-Ponte Queimada, 20/XII/1999, bo. fr., Temponi et al. 75 (VIC); Trilha do Aníbal, 12/IV/1999, fr., Temponi et al. 30 (VIC); Trilha da Campolina, 25/II/2000, bo. fr., Temponi et al. 94 (VIC); Trilha da Lagoa do Meio, 16/V/1999, fr., Temponi et al. 37 (VIC); Trilha da Mumbaça, 16/VIII/2000, fr., Temponi et al. 146 (VIC); Trilha do Vinhático, 23/III/2000, fl. fr., Temponi 97
(VIC); Fazenda do Bené Rico, 15/XI/2000, bo. fr., Temponi et al. 139 (VIC); Dionísio, Fazenda José Gomes, 8/VI/2000, fr., Temponi 117 (VIC).

4.2. Monstera praetermissa E.G. Gonç. \& Temponi, Britonia 56(1): 72-72. 2004.

Fig. 29-34

Hemi-epífita. Folha simples, pecíolo 62-210x 4-6 mm, sulcado na face adaxial; lâmina ovada-elíptica, fenestrada, leve assimétrica, 126-278×42-109 mm, ápice agudo-acuminado, base cuneado-obtusa, margem inteira, membranácea, verde nítido em ambas as faces; nervuras laterais primárias 12 pares, formando uma nervura coletora marginal irregular. Inflorescência 1 por axila foliar; pedúnculo verde, $69-102 \times 4-7 \mathrm{~mm}$, ereto, espata 3-5×1,8-3 cm, amarelo-alaranjada externa e internamente, decídua após antese; espádice séssil, 3,5-4×8-12 cm, amarelo-aranjado. Flor aclamídea, estames 4 , antera rimosa; gineceu prismático, ovário creme, 2 lóculos incompletos, 2 óvulos por lóculo, região estilar mais larga que o ovário, alaranjada, estigma 1,5-2,5 mm compr., alongado, fendido no centro, marrom na antese. Infrutescência 37-72×11-45 mm, alaranjada; pedúnculo curvado no ápice. Fruto 7-9,5×6,5-8,5 mm, prismático; semente 5,5-7× 4,5-5,5 mm, ovóide, lisa, 1-3 por baga.

Embora a espécie ocorra em vários estados brasileiros e espécimes já se encontravam depositadas em alguns dos principais herbários nacionais, estes se encontravam erroneamente identificados como Monstera obliqua Miq., uma espécie Amazônica (Gonçalves \& Temponi 2004). Diferencia-se desta última por apresentar uma a quatro inflorescências em cada simpódio floral (mais de seis em M. obliqua) e tricoesclereídes no ápice do gineceu. No Parque Estadual do Rio Doce, Monstera praetermissa foi representada por poucos indivíduos adultos, que floresceram em novembro e dezembro e frutificaram em dezembro, abril e junho.

Material selecionado: BRASIL. Minas Gerais: Marliéria, PERD: Margem da Lagoa Dom Helvécio, 13/XII/2000, fr., Temponi et al. 207 (VIC); Trilha da Lagoa do Anibal, 23/XII/1999, fl., Temponi et al. 84 (VIC).

5. Philodendron Schott, Wiener Z. Kunst 3: 828. 1829.

Herbáceo ou arbustivo. Reptante, escandente, epífita ou hemi-epífita, caule com crescimento simpodial. Folha simples ou composta; pecíolo levemente sulcado, algumas vezes, canaliculado ou alado, não geniculado no ápice; lâmina inteira, sectada, pinada ou palmada; nervação peniparalelinérvea. 

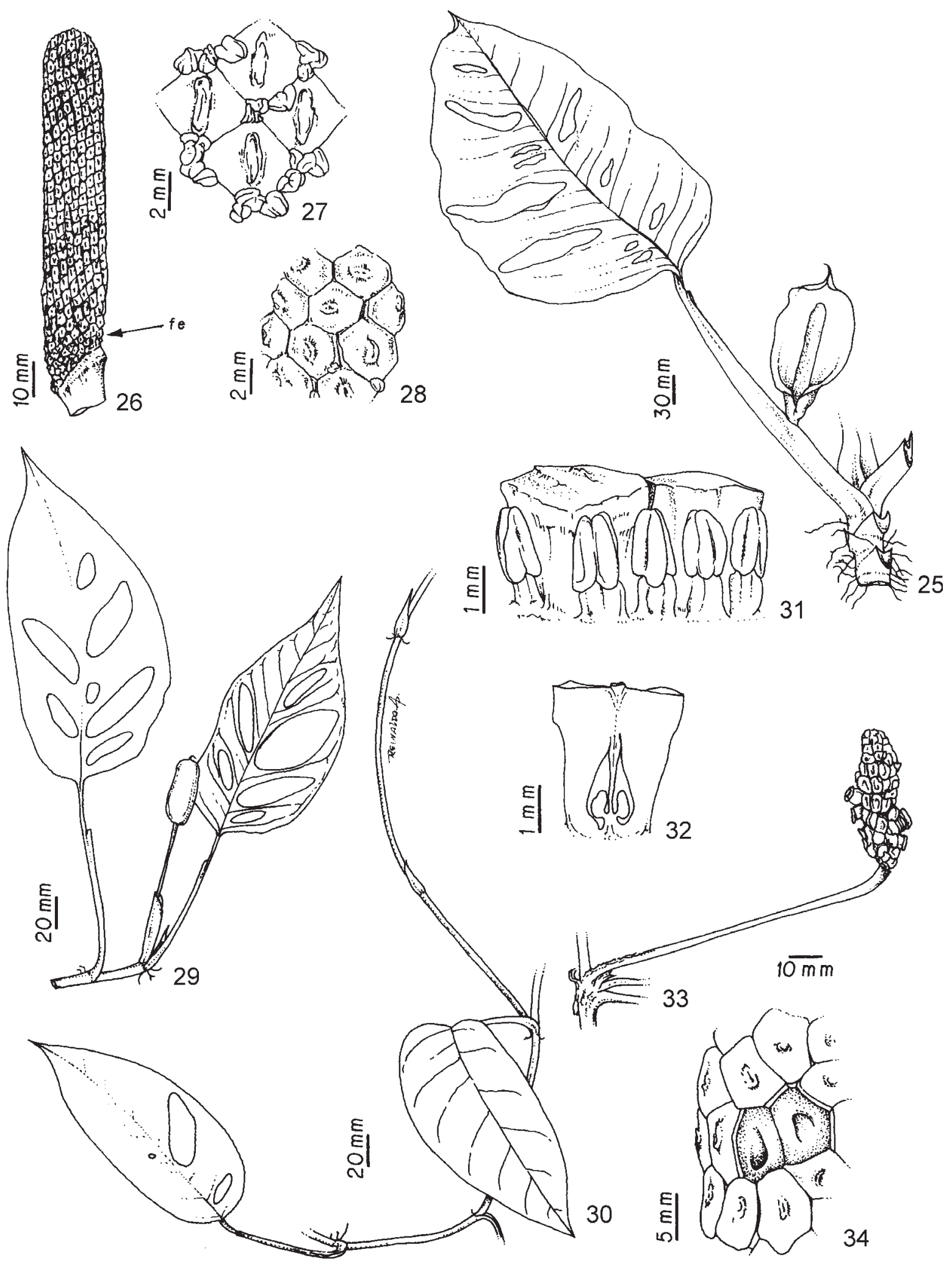

Figuras 25-34. Espécies de Monstera do PERD. 25-28. M. adansonii Schott. 25. Aspecto geral do ramo com inflorescência em antese. 26. Espádice homogêneo, fe = flores estéreis basais. 27. Flores bissexuais. 28. Flores estéreis basais (Temponi et al. 87 e 216). 29 -34. M. praetermissa E.G. Gonç. \& Temponi. 29. Aspecto geral do ramo. 30. Ramo jovem. 31. Vista longitudinal das flores bissexuais. 32. Corte longitudinal do gineceu. 33. Infrutescência imatura. 34. Frutos maduros, alguns sem a região estilar, evidenciando as bagas (Temponi et al. 29, 84 e 222). 
Inflorescência 1-11 por axila foliar, densiflora; espata persistente, decídua somente no fruto maduro, usualmente constricta, tubo com margens convolutas, lâmina ereta aberta, envolvendo o espádice após antese; espádice séssil ou curto estipitado, parcialmente adnato à espata, heterogêneo, região basal com flores femininas, região apical com flores masculinas, entre elas e, às vezes, no extremo ápice, flores masculinas estéreis. Flores unissexuais, aclamídeas; flor masculina, 2-6 estames livres; flor feminina, (2-)4-8(-47)-locular, 1-50 ou mais óvulos por lóculo, placentação axial, axial-basal, basal ou subbasal. Fruto isolado, subcilíndrico a ovóide; semente ovóide-oblonga ou elipsóide.

\section{Chave para identificação das espécies de Philodendron}

1. Ramos floríferos consistindo de uma sucessão de muitas folhas, ovadas a oblongas, com longas bainhas peciolares ou pecíolo alado; inflorescências solitárias; espata amarela, indiferenciada em lâmina e tubo

5.1. P. propinquum

1. Ramos floríferos consistindo de uma sucessão de curtos artículos simpodiais, cada um suportando um profilo bicarenado sem lâmina e uma folha sagitada com uma bainha foliar curta ou muito reduzida; inflorescências geralmente numerosas; espada diferenciada em lâmina e tubo

2. Esquâmulas intravaginais ocres, persistentes, folha com pecíolo $>65 \mathrm{~cm}$ compr., divisão anterior do limbo $>41 \mathrm{~cm}$ compr., zona estaminodial quase igual ou mais longa que a zona masculina fértil; estames geralmente muito finos, ao menos três vezes mais longos que largos .... 5.2. P. speciosum

2. Esquâmulas intravaginais negras, caducas; folha com pecíolo até $59 \mathrm{~cm}$ compr., divisão anterior do limbo até $40 \mathrm{~cm}$ compr., zona estaminodial sempre muito mais curta do que a zona masculina fértil; estames nunca três vezes mais longos que largos 5.3. P. vargealtense

\subsection{Philodendron propinquum Schott, Syn. Aroid.} 78. 1856.

Fig. 35-44

Hemi-epífita, herbácea; esquâmula intravaginal ausente; ramo flageliforme freqüente. Folha simples, pecíolo $90-125 \times 2,5-5 \mathrm{~mm}$, alado, esverdeado com máculas verde escuro, bainha peciolar longa, às vezes, com lígula; lâmina ovada, oblonga-ovada ou oblongoelíptica, 102-228×37-85 mm, ápice acuminado, base obtusa, margem inteira a levemente ondulada, membranácea, levemente discolor, verde-amarelada na face abaxial; nervuras laterais primárias 7-9 pares, verde amareladas, levemente impressas. Inflorescência 1 por axila foliar; pedúnculo ereto, $22-25 \times 4,5-8 \mathrm{~mm}$; espata 70-105×41-49 mm, não constricta, persistente, amarela com ápice esverdeado; espádice estipitado, 62-92 mm compr.; zona estaminada $35-50 \times 5-15 \mathrm{~mm}$, creme-esbranquiçada; zona estaminada estéril 5-10×11-13 mm, creme a rosa escuro; zona pistilada 25-34×10-11 mm, não adnata à espata, verdeamarelada; estípite ca. $1 \mathrm{~cm}$ compr. Flor masculina 2(-3) estames, 1,5-2,0×1-1,5 mm; flor feminina, ovário oblongo, 3-4-locular, vários óvulos por lóculo, placentação axial, região estilar mais larga que o ovário, estigma papiloso. Fruto não visto.

$P$. propinquum é uma espécie amplamente distribuída na Mata Atlântica brasileira. No Parque Estadual do Rio Doce, foi encontrada em muitas trilhas, mas apenas no interior da mata. Apresentou floração e frutificação concentrada nos meses de outubro a dezembro. Philodendron propinquum é facilmente reconhecida pela presença de uma bainha expandida, ao longo de todo o pecíolo, às vezes mais longa que o próprio pecíolo, constituindo a lígula.

Material selecionado: BRASIL. Minas Gerais: Marliéria, PERD: Trilha da Lagoa do Meio, 31/X/1999, bo., Temponi et al. 58 (VIC); Trilha da Lagoa Preta, 16/X/2000, bo. fr., Temponi et al. 155 (VIC); Trilha do Vinhático, 16/XI/2000, bo. fl. fr., Temponi et al. 181 (VIC).

\subsection{Philodendron speciosum Schott ex Endl., Gen.} Pl. 1(3): 237. 1837.

Fig. 45-56

Hemi-epífita, arbustiva; esquâmula intravaginal 1-3 mm compr., ocre, triangular, persistente. Folha simples; pecíolo, 65-110×1,4-2,1 cm, lâmina sagitada, $63,5-84 \times 69-94 \mathrm{~cm}$, ápice agudo, margem inteira a levemente ondulada, coriácea, verde nítido na face adaxial; divisão anterior $41-58 \times 35,5-52 \mathrm{~cm}$, nervuras laterais primárias 7-9 pares; divisões posteriores 22,5-26×33,5-42 cm. Inflorescência 1 por axila foliar; pedúnculo ereto, $13-15,5 \times 1,2-1,7 \mathrm{~cm}$; espata $24-39 \mathrm{~cm}$ 


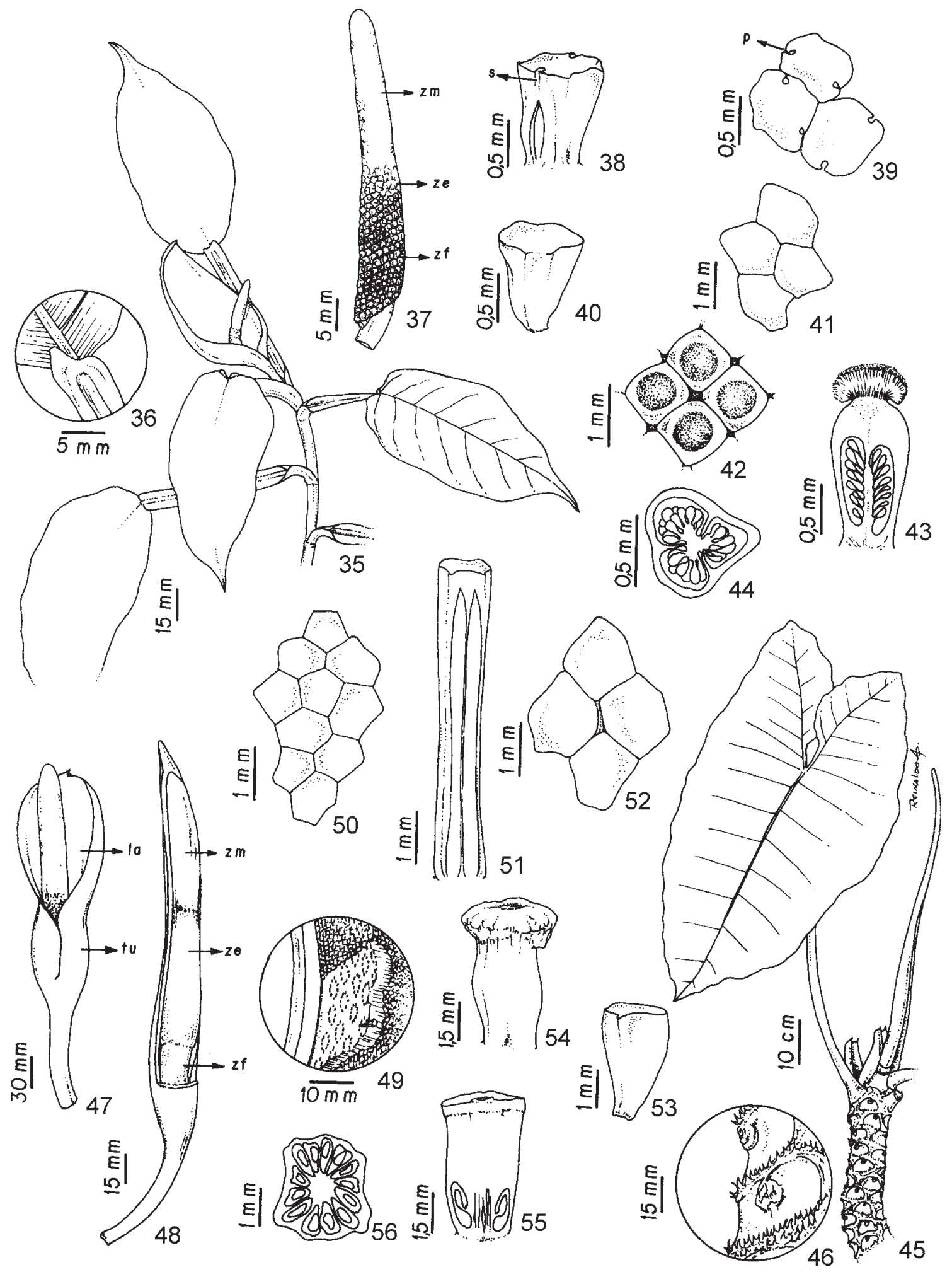

Figuras 35-56. Espécies de Philodendron do Parque Estadual do Rio Doce. 35-44. P. propinquum Schott. 35 . Aspecto geral do ramo. 36. Lígula. 37. Espádice heterogêneo, $\mathrm{zf}=$ zona feminina, $\mathrm{ze}=$ zona masculina estéril e $\mathrm{zm}=$ masculina. 38 . Vista longitudinal do estame, $\mathrm{s}=$ sulco. 39. Vista frontal dos estames, $\mathrm{p}=$ poro. 40-41. Vista longitudinal e frontal de estames estéreis, respectivamente. 42. Vista frontal das flores femininas. 43. Corte longitudinal da flor feminina. 44. Corte transversal do ovário (Temponi et al. 181). 45-56. P. speciosum Schott. 45. Aspecto geral do ramo. 46. Detalhe da cicatriz foliar. 47. Inflorescência, tu = tubo, la = lâmina. 48. Espádice, $\mathrm{zf}=$ zona feminina, ze = masculina estéril e zm = masculina. 49. Cicatriz dos estaminódios. 50-51. Vista frontal e longitudinal dos estames, respectivamente. 52-53. Vista frontal e longitudinal dos estaminódios. 54-55. Vista e corte longitudinal da flor feminina. 56. Corte transversal do ovário (Temponi et al. 179 e 215 ). 
compr., levemente constricta, verde externamente e vermelha internamente, persistente; lâmina $15-22 \times$ 3,9-8 cm; tubo 12-13×3,2-5 cm; espádice estipitado, 21-37,5 cm compr.; zona estaminada $105 \times 19-22,5 \mathrm{~mm}$, creme-esbranquiçada; zona estaminada estéril $125 \times 19-29 \mathrm{~mm}$, creme-esbranquiçada; zona pistilada 21-46,5×1,9-2,7 cm, amarelada, não adnata à espata; estípite 1,8-4,6 cm. Flor masculina, 10 estames livres 5,5-6,5×1 mm; flor feminina, ovário subprismático, 18-19-locular, lóculos uniovulados, placentação axialbasal, estigma papiloso 3-4 mm diâm. Infrutescência imatura 83-130×31-37 mm, creme; pedúnculo pêndulo. Fruto não visto.

Essa é sua primeira citação de ocorrência em Minas Gerais, ampliando sua área de distribuição, até então, relatada apenas para o Rio de Janeiro. No Parque Estadual do Rio Doce, Philodendron speciosum foi encontrado tanto no extrato superior na mata, quanto em bordas de estradas e margens de lagoas, em quase todas as trilhas. Philodendron speciosum floreceu em junho, novembro e dezembro e frutificou em vários meses do ano.

Material selecionado: BRASIL. Minas Gerais: Marliéria, PERD: Estrada Cava Grande-Ponte Queimada, 14/XII/2000, bo. fl. fr., Temponi et al. 215 (VIC); Estrada do Restaurante, 7/IV/2000, fr., Temponi et al. 112 (VIC); Margem da Lagoa Dom Helvécio, 16/XI/2000, bo. fr., Temponi 179 (VIC); Trilha da Lagoa Carioca, 12/VII/1999, fr., Temponi et al. 215 (VIC).

\subsection{Philodendron vargealtense Sakuragui, Novon} 11(1): 102-104. 2001.

Fig. 57-65

Hemi-epífita, herbácea; esquâmula intravaginal negra 0,1-0,15 mm, triangular, caduca. Folha simples; pecíolo 31-59×0,6-1,18 cm, levemente sulcado, lâmina sagitada, 31-55×31-59,6 cm, ápice agudo, margem inteira a levemente ondulada, cartácea, verde nítido na face adaxial; divisão anterior 22-39,5×12,7-29,6 cm, nervuras laterais primárias de 10-16 pares; divisões posteriores $8-15,8 \times 18,5-20 \mathrm{~cm}$. Inflorescência 1-3 por simpódio floral; pedúnculo ereto, $3-7,8 \times 2,9 \mathrm{~cm}$; espata 11-12,8 cm compr., constricta, verde externamente, vermelha internamente, pelo menos até região de constrição, persistente, lâmina $70-85 \times 54-55 \mathrm{~mm}$, tubo 49-50×20-29 mm; espádice curto-estipitado, 8,9-12,4 cm compr.; zona estaminada 56-83×8-9,5 mm, amarelada; zona estaminada estéril $5,5-7 \times 8-10 \mathrm{~mm}$, amarelo-rosado; zona pistilada $29-36 \times 8,5-11 \mathrm{~cm}$, esverdeada, não adnata à espata; estípite 5,5-7 $\mathrm{mm}$.
Flores; flor masculina 2-4 estames, 0,8-2×1-1,5 mm; flor feminina, ovário subprismático, 8-9-locular, óvulos 4-6 por lóculo, funículo com tricomas, placentação axialbasal, estigma globoso. Fruto não visto.

A ocorrência de Philodendron vargealtense no Parque Estadual do Rio Doce amplia a sua distribuição geográfica até então só registrada em Vargem Alta (ES), onde foi considerada endêmica (Sakuragui 2001). Essa espécie ocorreu no sub-bosque, em apenas três das 11 trilhas percorridas no Parque. Philodendron vargealtense apresentou dois períodos de floração; de outubro a janeiro e em julho. A frutificação durou vários meses do ano.

Material selecionado: BRASIL. Minas Gerais: Marliéria, PERD: Trilha da Campolina, 21/XI/1999, bo. fr., Temponi et al. 69 (VIC); Trilha da Lagoa do Meio, 17/X/2000, bo. fr., Temponi et al. 164 (VIC).

\section{Rhodospatha Poepp., Nov. Gen. Sp. Pl. 3:91. 1845.}

Erva perene, usualmente trepadeira ou hemiepífita, raramente arbustiva. Folha simples; pecíolo canaliculado, geniculado no ápice; bainha longa persistente ou marcescente; lâmina inteira, oblonga; nervação peniparalelinérvea, com nervuras de ordens superiores às laterais terciárias, transversalmente reticuladas. Inflorescência 1 por axila foliar, densiflora; espata caduca, não constricta, ereta, aberta, ovada ou oblongo-ovada; espádice séssil a longo estipitado, não adnato à espata, homogêneo, algumas vezes flores basais estéreis ou femininas. Flores bissexuais, aclamídeas; estames 4, livres; ovário 2-locular, muitos óvulos por lóculo, placentação axial, raramente subbasal, região estilar distinta, mais larga que o ovário. Fruto isolado, cilíndrico a prismático; semente arredondada a reniforme, achatada.

\subsection{Rhodospatha sp.}

Fig. 66-72

Helófita, arbustiva. Folha simples; pecíolo 25-62 $\times 0,3-2 \mathrm{~cm}$, verde a verde amarelado; genículo 3,5-5×0,5-1 cm; lâmina oblonga, 22-39× 9-23,5 cm, ápice agudo, base cuneada, margem inteira, levemente discolor, verde nítido na face adaxial, nervuras laterais primárias mais de 20 pares. Inflorescência 1 por axila foliar; pedúnculo ereto, $12-34 \times 0,55-2,5 \mathrm{~cm}$; espata 15-15,8×6,5-7,1 cm, não constricta, decídua após a antese; espádice curto estipitado, 55-130×8,5-45 mm, rosado a rosa escuro; estípite 4-8 $\mathrm{mm}$. Estames 4 , filete achatado; gineceu retangular, rosado, 2-locular, muitos óvulos por lóculo, região estilar mais larga que o ovário, estigma ca. 1-1,5 mm compr., alongado, fendido no 


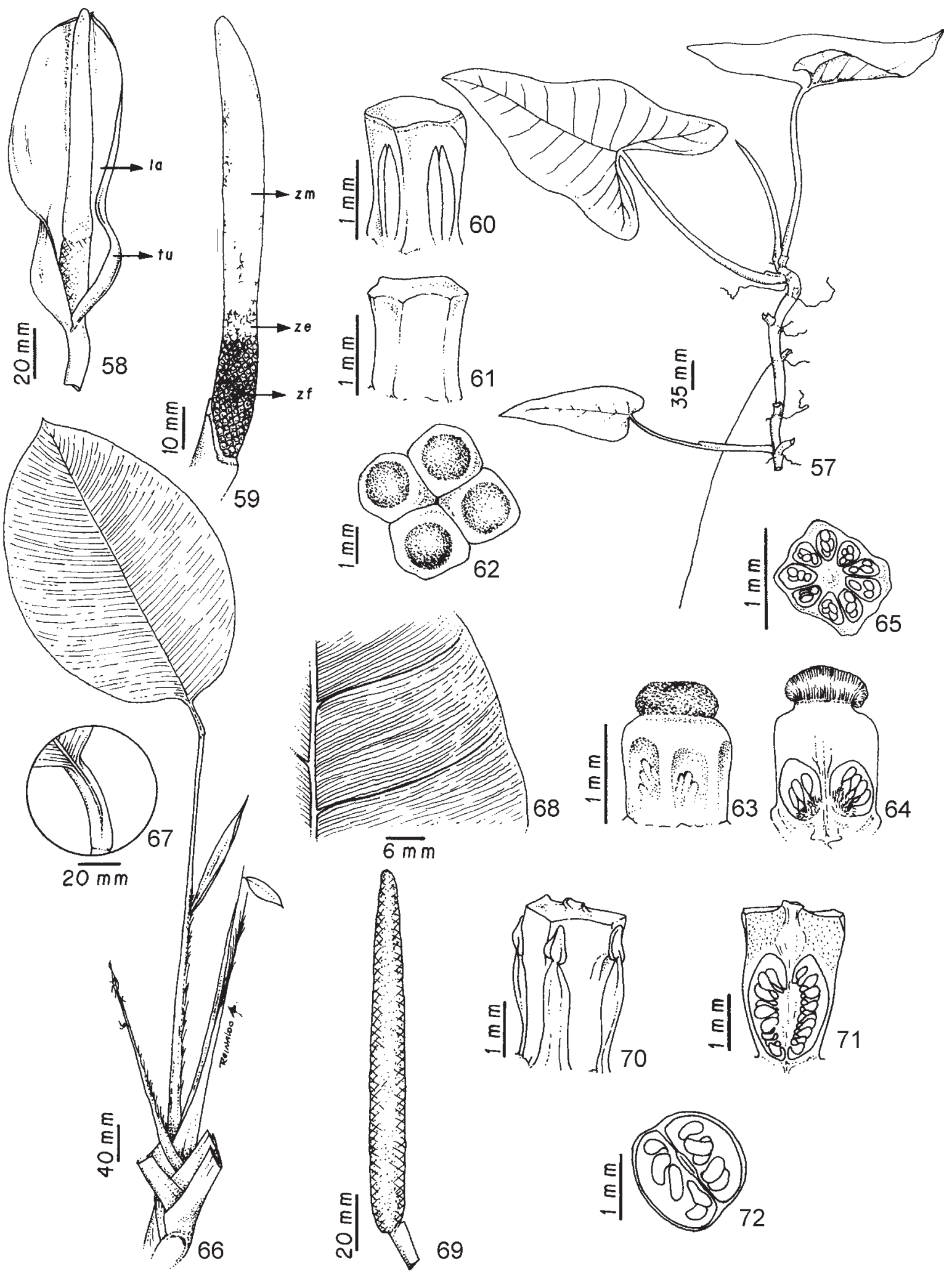

Figuras 57-72. Philodendron vargealtense Sakuragui e Rhodospatha sp. 57-65. P. vargealtense. 57 Aspecto geral do ramo. 58. Inflorescência, $\mathrm{tu}=$ tubo e la = lâmina. 59. Espádice, $\mathrm{zf}=$ feminina, $\mathrm{ze}=$ masculina estéril e $\mathrm{zm}=$ masculina. 60 . Vista longitudinal do estame. 61. Vista longitudinal do estaminódio. 62. Vista frontal das flores femininas. 63-64. Vista e corte longitudinal de uma flor feminina, respectivamente. 65. Corte transversal do ovário (Temponi et al. 164, 187 e 223). 66-72. Rhodospatha sp. 66. Aspecto geral do ramo. 67. Genículo. 68. Venação peniparalelinérvea. 69. Espádice homogêneo. 70. Vista longitudinal da flor. 71-72. Cortes longitudinal e transversal do ovário, respectivamente (Temponi et al. 105 e 220). 
centro. Infrutescência imatura $20-15 \times 1,5-2,2 \mathrm{~cm}$; pedúnculo ereto. Fruto imaturo subprismático; semente reniforme.

Rhodospatha sp. foi observada no interior da mata de apenas duas trilhas do Parque com distribuição em áreas por onde escoa água ou permanece mais úmido nos meses chuvosos. Há registro da ocorrência desta espécie de Rhodospatha apenas em Caratinga, MG. Rhodospatha sp. floresceu de outubro a dezembro. Fruto imaturo foi observado em novembro, dezembro e março. A espécie distinguiu-se das demais espécies do Parque Estadual do Rio Doce por ser a única arborescente com folha com venação peniparalelinérvea e flores bissexuais.

Estes espécimes coletados no Parque Estadual do Rio Doce, assim como os coletados na Estação Ecológica de Caratinga, representam uma nova espécie e está em preparação para publicação.

Material selecionado: BRASIL. Minas Gerais: Marliéria, PERD: Trilha da Lagoa Preta, 25/III/2000, fr., Temponi et al. 105 (VIC); Fazenda Bené Dias, 13/XII/2000, fr., Temponi et al. 210 (VIC).

\section{Syngonium Schott, Wiener Z. Kunst 3: 780. 1829.}

Erva perene, escandente, hemi-epífita, com látex; caule com crescimento simpodial. Folha simples; pecíolo canaliculado, invaginado na base; bainha longa; lâmina inteira ou sectada, trífida, pedatífida ou raramente pinatífida, nervuras laterais primárias pinadas, nervuras laterais secundárias e de ordens superiores reticuladas. Inflorescência 1-8 por axila foliar, densiflora; espata parcialmente persistente, fortemente constricta, tubo convoluto, persistente, lâmina ereta aberta, marcescente e decídua após antese; espádice séssil, não adnato à espata, heterogêneo, região basal com flores femininas, conatas entre si, região apical com flores masculinas férteis, entre as duas regiões, zona masculina estéril constricta. Flores unissexuais, aclamídeas; flor masculina, 2-4 estames, conatos em um sinândrio; flor feminina, (1)-2-(3)-locular, 1-(2) óvulos por lóculo, placentação axial, axial-basal ou sub-basal. Fruto composto, bagas conatas formando um fruto cilíndrico; semente ovóide a elipisóide.

7.1. Syngonium vellozianum Schott, Oest. Bot. Wochenbl. 4: 418. 1854.

Fig. 73-81

Hemi-epífita; ramo flageliforme freqüente. Folha simples; pecíolo 16-53×0,2-0,65 cm, sulcado; lâmina jovem sagitada; adulta tripartido-hastada ou com cinco lobos incompletamente separados, membranáceos, verde em ambas as faces; divisão anterior 13-28×5,8$16,5 \mathrm{~cm}, 1$ lobo obovado, ápice agudo, margem levemente ondulada, nervuras laterais primárias 4-9 pares; divisões posteriores 9-23×5,8×16,5-18 cm, 1 lobo ou quando 2, não inteiramente livres, semelhantes ao lobo da divisão anterior. Inflorescência 5-8 por simpódio floral; pedúnculo ereto, $25-80 \times 8-12 \mathrm{~mm}$, verde; espata constricta, parcialmente persistente, lâmina 19-38,5×39 mm, amarelada, tubo $24-27,5 \times 18 \mathrm{~mm}$, verde; espádice séssil, 5,8-6 cm compr.; zona estaminada 30-39 $\times 10-11 \mathrm{~mm}$, branca; zona estaminada estéril 8,5-9,5×4,5-5 $\mathrm{mm}$, branca; zona pistilada $13,5-15,5 \times 9-9,5 \mathrm{~mm}$, verde-amarelado, não adnata à espata. Flores; flor masculina 3-4 estames conatos em sinândrio; flor feminina, ovário creme, 2 lóculos, uniovulados, placentação axial-basal, estigma discóide branco-esverdeado. Fruto alaranjado; pedúnculo pêndulo; semente 6-7,5 $\mathrm{mm}$ diâm., 2 por fruto, cilíndrica.

É uma espécie encontrada nas matas úmidas neotropicais (Croat 1981). No Parque Estadual do Rio Doce, ocorre geralmente no interior da mata, em quase todas as trilhas. Syngomium vellozianum foi a espécie mais observada em fase reprodutiva, apresentando-se completamente estéril somente em janeiro. Pode ser facilmente reconhecida por apresentar látex branco, espata fortemente diferenciada em tubo e lâmina, parcialmente persistente (lâmina é decídua após antese) e as bagas fundidas, formando um fruto composto.

Em um trabalho de revisão de Syngonium, Croat (1981) sugeriu sua sinonimização para S. podophyllum Schott, por considerar inconsistente o grau de fusão dos lobos foliares, caracter apontado como diagnóstico por Engler \& Krause (1920). Entretanto, neste trabalho foi possível observar em S. vellozianum outras características distintas das encontradas em S. podophyllum, que apresenta infrutescência comumente vermelha, lâmina pedati-5-7-9-11 secta com lobos foliares sempre livres.

Material selecionado: BRASIL. Minas Gerais: Marliéria, PERD: Trilha da Campolina, 21/XII/1999, bo. fl. fr., Temponi et al. 81 (VIC); Trilha da Garapa Torta, 14/VIII/2000, bo. fl. fr., Temponi et al. 134 (VIC); Trilha da Lagoa do Meio, 31/X/1999, bo. fl. fr., Temponi et al. 62 (VIC); Trilha da Lagoa Preta, 15/VII/2000, est., Temponi et al. 136 (VIC); Trilha do Vinhático, 10/VII/1999, bo. fr., Temponi et al. 45 (VIC); Fazenda do José Gomes, 8/VI/2000, fr., Temponi et al. 118 (VIC). 


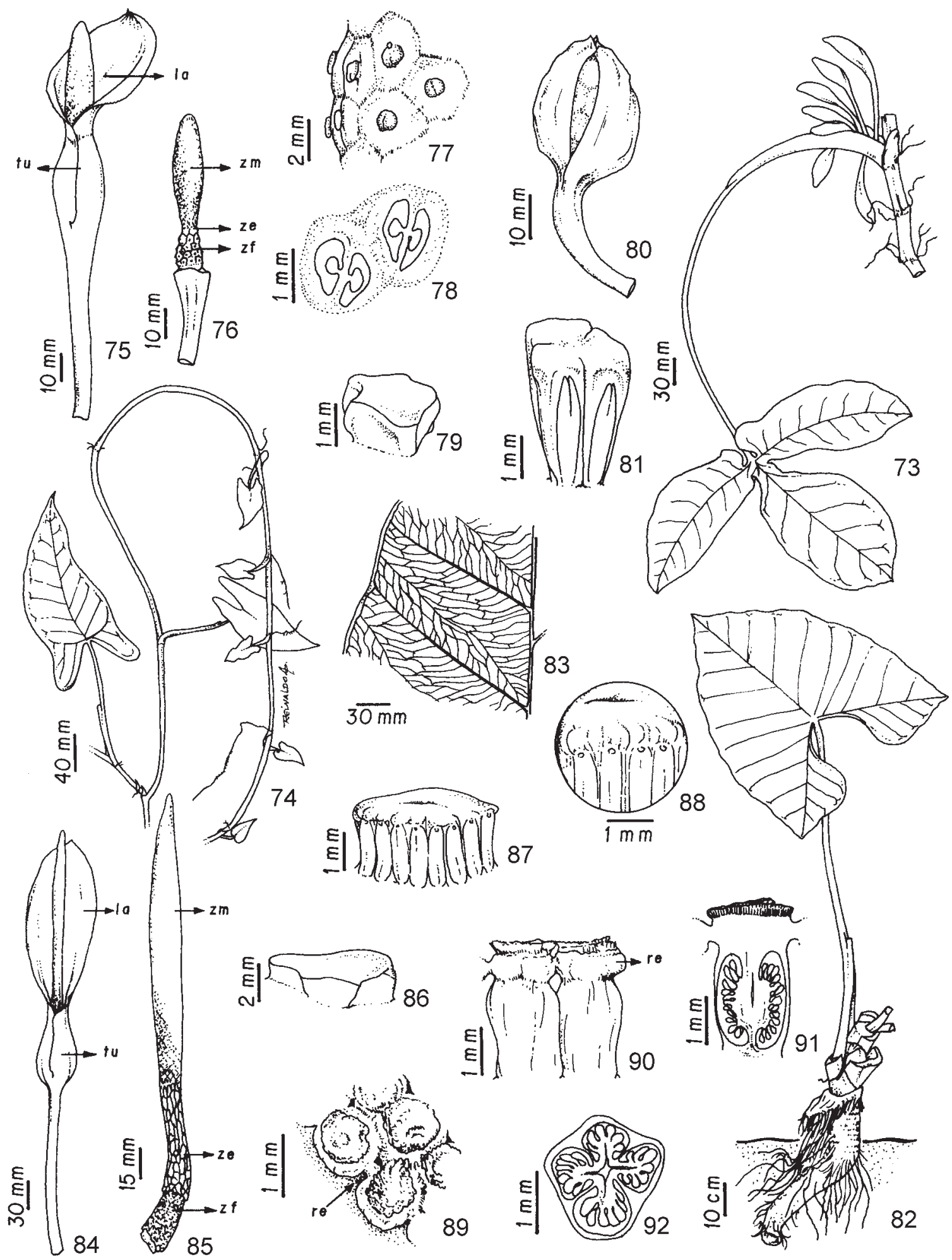

Figuras 73- 92. Espécies de Syngonium e Xanthosoma do Parque Estadual do Rio Doce. 73-81. S. vellozianum Schott. 73. Aspecto geral do ramo. 74. Ramo flageliforme. 75. Inflorescência, tu = tubo, la = lâmina. 76. Espádice, $\mathrm{zf}=$ zona feminina, ze = zona masculina estéril e $\mathrm{zm}=$ zona masculina. 77. Vista frontal de flores femininas. 78. Corte transversal de flores femininas. 79. Vista longitudinal do estaminódio. 80. Fruto composto. 81. Vista longitudinal do sinândrio (Temponi et al. 157, 192 e 224). 82-92. X. maximiliani Schott. 82. Hábito. 83. Venação colocasióide. 84. Inflorescência, tu = tubo e la = lâmina. 85. Espádice, zf = zona feminina, ze = zona masculina estéril e zm = zona masculina. 86. Vista longitudinal do estaminódio. 87. Vista longitudinal do sinândrio. 88. Poro subapical. 89-90. Vista frontal e longitudinal de flores femininas, respectivamente, $r e=$ região estilar. 91. Corte longitudinal da flor feminina. 92. Corte transversal do ovário (Temponi et al. 178). 
8. Xanthosoma Schott, Melet Bot. 19. 1832.

Erva sazonal ou perene, ocasionalmente arbustiva, com látex; caule tuberoso a ereto. Folha simples ou composta; pecíolo canaliculado a sulcado; lâmina geralmente cordada, hastada, sagitada, trifida, pedatífida, 3-5secta, raramente linear-lanceolada a ovada; nervação colocasióide. Inflorescência 1-várias por axila foliar, densiflora; espata parcialmente persistente, fortemente constricta, tubo com margem convoluta, persistente, lâmina ovada ou oblonga, ereta aberta ou, algumas vezes, reflexa, marcescente e decídua após a antese; espádice geralmente séssil, não adnato à espata, heterogêneo, região basal com flores femininas, região apical com flores masculinas férteis, entre as duas regiões, zona masculina estéril constricta. Flores unissexuais, aclamídeas; flor masculina, 4-6 estames conatos em um sinândrio; flor feminina, 2-4locular, lóculos incompletamente a totalmente individualizados, (12-)-muitos óvulos por lóculo, placentação axial, axial-basal ou parietal, região estilar distinta, mais larga que o ovário. Fruto isolado, cilíndrico; semente ovóide.

\subsection{Xanthosoma maximiliani Schott, Bonplandia 10:} 322. 1862.

Fig. 82-92

Helófita, arbustiva. Folha simples, pecíolo 74-150×1,35-4,2 cm sulcado; lâmina foliar sagitada, $36-87 \times 46,5-163,5 \mathrm{~cm}$, sagitada, ápice agudo, margem inteira, verde nítido na adaxial; divisão anterior $23,5-60 \times 22,5-80,5 \mathrm{~cm}, 4-8$ pares de nervuras laterais primárias; divisões posteriores $13-26,5 \times 24-83 \mathrm{~cm}$. Inflorescência 7-11 por simpódio floral; pedúnculo ereto 20-36 $\times 1,1-1,8 \mathrm{~cm}$; espata constricta, parcialmente persistente, lâmina $125-185 \times 43,5-70 \mathrm{~mm}$, branca, tubo 60-89×36-45 mm, esverdeado com estrias vináceas externamente, internamente vinho a negro; espádice séssil, 17-18,5 cm compr.; zona estaminada 103-112×8,5-12,5 mm, branca; zona estaminada estéril 29-33 $\times 6-10,5 \mathrm{~mm}$, creme a rosada; zona pistilada 20-27×11,5-19 mm, alaranjada-escuro, não adnata à espata. Flores aclamídeas; flor masculina 6 estames conatos em sinândrio, $3 \times 2,5-3,5 \mathrm{~mm}$; deiscência por poro subapical; flor feminina 4 lóculos, muitos óvulos por lóculo, placentação axial, região estilar adnata à das flores vizinhas, estigma papiloso. Infrutescência imatura esverdeada; pedúnculo ereto. Fruto não visto.

Xanthosoma maximiliani ocorre em matas dos estados do sudeste e nordeste brasileiros e foi encontrado em apenas duas trilhas do Parque Estadual do Rio Doce. A floração e frutificação de Xanthosoma maximilianii se concentrou nos meses de novembro e dezembro. Na maioria das vezes, o mesmo indivíduo apresentou inflorescências em pré-antese, antese, pósantese e frutos imaturos, revelando que o período reprodutivo para esta espécie é muito curto. Facilmente identifificada pelo hábito arborescente, lâmina foliar sagitada com venação colocasióide, flor feminina alaranjada-escuro, espata fortemente constricta com a região do tubo verde com estrias vinho externamente, formando internamente uma câmara vinho a nigrescente.

Material selecionado: BRASIL. Minas Gerais: Marliéria, PERD: Trilha da Lagoa Preta, 22/XII/1999, bo. fl. fr., Temponi et al. 82 (VIC); 15/XI/2000, bo. fr., Temponi et al. 178 (VIC);

\section{Agradecimentos}

As autoras agradecem aos Curadores dos herbários BHCB, R, RJ, SP e SPF e aos especialistas Marcus A. Nadruz Coelho, Eduardo G. Gonçalves, Simon J. Mayo e Thomas B. Croat pelo envio de bibliografia e os valiosos esclarecimentos sobre a morfologia do grupo; ao Reinaldo Antônio Pinto, pelas ilustrações; à Fundação O Boticário/MacArthur Foudation, pelo financiamento do projeto; à CAPES, pela Bolsa de Mestrado concedida à primeira autora.

\section{Referências bibliográficas}

Aubrèville, A. 1959. As florestas do Brasil-estudo fitogeográfico florestal. Anuário Brasileiro de Economia Florestal 11: 201-232.

Brummitt, R.K. \& Powell, C.E. 1992. Authors of plant names. Kew, Royal Botanical Garden.

Croat, T.B. 1981. A revision of Syngonium (Araceae). Annals of the Missouri Botanical Garden 68: 565-651.

Croat, T.B. 1985. Collecting and preparing specimens of Araceae. Annals of the Missouri Botanical Garden 72: 252-258.

Croat, T.B. \& Bunting, G.S. 1979.Standardization of Anthurium descriptions. Aroideana 2(1): 15-25.

Engler, A. 1878. Araceae. Pp. 3(2): 25-284. In: C.F.P. Martius (ed.). Flora Brasiliensis. Leipizig, Frid. Fleischer.

Engler, A. 1905. Araceae-Pothoideae. Pp. 21 (IV.23B). 1-330. In: A. Engler (ed.). Das Pflanzenreich. Engelman, Leipizig \& Berlin.

Engler, A. 1920. Araceae-Aroideae. Araceae-Pistioideae. Pp. 73 (IV. 23F): 1-274. In: A. Engler (ed.). Das Pflanzenreich. Engelman, Leipizig \& Berlin.

Engler, A. \& Krause, K. 1920. Araceae-Colocasioideae. Pp. 71 (IV.23E): 1-139. In: A. Engler (ed.). Das Pflanzenreich. Engelman, Leipizig \& Berlin. 
Gonçalves E.G. 1999. A revised key for the genus Asterostigma C.A. Fisch. \& Mey. (Araceae: Tribe Spathicarpeae) and a new species from Southeastern Brazil. Aroideana 22: 30-33.

Gonçalves, E.G. 2001. A new Anthurium (Araceae) from Serra do Cipó, Brazil. Aroideana 24: 6-11.

Gonçalves, E.G. \& Temponi, L.G. 2004. A new Monstera (Araceae: Monsteroideae) from Brazil. Brittonia 56(1): 72-74.

Madison, M.T. 1977. A revision of Monstera (Araceae). Contribution from the Herbarium Harvard University 207: 1-101.

Mayo, S.J. 1990. Problems of speciation, biogeography and systematic in some Araceae of the Brazilian Atlantic Forest. Pp. 235-258. In: Anais do II Simpósio de Ecossistemas da Costa Sul e Sudeste Brasileira. São Paulo, 1990. Watanabe et al. Ed. I. São Paulo.

Mayo, S.J. 1991. A revision of Philodendron subgenus Meconostigma (Araceae). Kew Bulletim 46(1): 601-681.

Mayo, S.J.; Borgner, J. \& Boyce, P.C. 1997. The genera of Araceae. Kew, Royal Botanic Gardens.
Peyritsch, J.J. 1879. Aroideae Maximilianae. Viena, Carl Gerold's Sohn.

Radford, A.E.; Dickison, W.C.; Massey, J.R. \& Bell, C.R. 1979. Vascular plant systematics. New York, Harper \& Row Publishers.

Sakuragui, C.M. \& Mayo, S.J. 1997. Three new species of Philodendron from South-eastern Brazil. Kew Bulletim 52(3): 673-682.

Sakuragui, C.M. 2001. Two new species of Philodendron (Araceae) from Brazil. Novon 11(1): 102-104.

Schott, H.W. 1856. Synopsis Aroidearum. Pp.126. Vienna, Typis congregations mechitharisticae.

Temponi, L.G.; Garcia, F.C.P.; Sakuragui, C.M. \& CarvalhoOkano, R.M. 2005. Diversidade de formas de vida das Araceae no Parque Estadual do Rio Doce, Minas Gerais. Rodriguésia 56(88): 1-13.

Veloso, H.P.; Rangel Filho, A.L.R. \& Lima, J.C.A. 1991. Classificação da vegetação Brasileira, adaptada a um sistema universal. Rio de Janeiro, IBGE. 